\title{
The Role of Marketing Capabilities in Innovation Based Competitive Strategies: An Application on Production Businesses in Ankara
}

\author{
Tülin Durukan \\ Associate Professor, Faculty of Economics and Administrative Sciences \\ Department of Marketing, Kirikkale University, 71450, Kirikkale, TURKEY \\ A. Buğra Hamşioğlu \\ PhD, Faculty of Economics and Administrative Sciences, \\ Department of Marketing Kafkas University, 36100, Kars, TURKEY
}

\begin{abstract}
The developments experienced in the business world have instigated the intensity and severity of current competition. The existence struggle of companies within this intensive and severe competitive environment is based on their performance development. This compels businesses to focus on their marketing capabilities along with their innovative and entrepreneurial endeavors. Thus, business can enhance sustainable competitive advantage with their sources and capabilities they have. Furthermore, in order to achieve this objective, businesses shall structure their marketing capabilities. With respect to this, this study is rested on an empirical study conducted in two main sectors in the province of Ankara determining marketing capacities in innovative competitive strategies. Regarding this, the results were evaluated with 165 questionnaires in 192 different companies. According to the findings, there are positive and significant correlations of intensive entrepreneurship on marketing capacities, marketing capacities on organizational innovativeness and sustainable competitive advantage as well as organizational innovativeness on competitive advantage.
\end{abstract}

Key Words: Marketing Capability, Organizational Innovation, Sustainable Competitive Advantage

\section{INTRODUCTION}

At the last ten years, researchers have shown great interest in role of marketing in strategic management. Some of the researchers have observed that marketing function has lost its formal organization status within many international organizations and they also have mentioned that most important point is that there has been a loss in faith in marketing management as a strategical power (Piercy, 1998:222-236). As is mentioned in strategic dialog of Kerin as of (1992), functional role of marketing, marketing and important matters in strategic management are disregarded by marketing scientists. Kerin (1992) also thinks that distinctive capabilities should be discovered as a new subject of a research related with innovative and entrepreneur administration behaviors. Functional role of the administration in strategical management is interested in entrepreneurship and in innovation and expansion properties of the administration and briefly these are named as innovation (Kerin, 1992:332).

By the capability based theory of competition advantage, it is suggested that administrations having distinctive capabilities shall obtain competitive advantage. Despite of the fact that importance of researches has increased in literature, numbers of studies examining the role of 
innovation based competitive advantage have been limited. Conceptualization of innovation, missing points and structure of sustainable competitive advantage has been reflected within previous researches (Weerawardene, 2003:16). In this study, entrepreneurship, marketing ability, organizational innovation relations have been tested and their impacts over sustainable competitive advantage have been examined and the outputs have been used in strategic marketing literature.

During the study process of this article; (1) sustainable competitive advantage theory has been examined by focusing on role of distinctive capabilities within innovation based competitive strategy, (2) test of conceptual structures has been aimed and conceptual frame explaining theoretical relations has been handled for this purpose, (3) methods which have been used to test composed hypothesis have been discussed and (4) 165 questionnaires performed within 192 manufacturing administrations active in two different sectors have been analyzed and results have been presented.

\section{THEORETICAL FRAMEWORK: ROLE OF COMPETITIVE ADVANTAGE AND DISTINCTIVE CAPABILITIES}

The capability based theory suggests that an administration is able to obtain competitive advantage by the help of its distinctive capabilities and it is required for the administration to improve its current abilities in order to continuously keep its existence and in order to prevent its imitability and it is also required for the administration to invest again and again. Innovation based theory within the resource based competitive advantage view has been developed in the last few years and it is mentioned that administrations are stacks of resources and capabilities (Prahalad and Hamel, 1990:79-91; Mahoney, 1995:91-101; Barney, 1991:99120; Peteraf, 1993:179-192). Focus of resource based competitive view is to allocate, define resources and capabilities of the administration and them to be implemented for a sustainable competitive advantage (Collis, 1994:143-152). However some of the researchers argue that a resource based strategy shall not be sufficient by itself in order to support competitive advantage. It is generally thought that the administrations which are able to respond the demands on time, rapidly and by flexible product innovations shall be more successful compared to the other ones in gaining within the global market. The important point is not only to determine what the administrations can do or how good they are able to perform this job but also strategical leadership (Teece et. al, 1997:509-533; Grant, 2010:120-149).

Determination of framework of capability based theory is different than other competitive strategy models and here, the fact of the administration having an entrepreneur structure and key roles played by decision makers in building of sustainable competitive advantage is important. Selznick has emphasized the importance of theoretical leadership in administrations at the study he has performed as of (1957) while defining distinctive capabilities. He has mentioned this as one the most significant factors having impact over the power or weakness of the administrations. At the analysis of special capability (power and weakness), environmental opportunities and threats have been evaluated together (Lado et al., 1992:77-91). Reed and Defilippi have developed distinctive capabilities concept at (1990) during the study they have performed to analyze the relation in between sustainable competitive advantage and causal uncertainty (Reed and DeFillippi, 1990:88-102). Causal uncertainty is described as "basic uncertainty" related with the nature of causal links in between actions and results (Lippman and Rumelt, 1982:420). It is defined as potential of this administration to produce superior performance due to its resources and capability (Reed and DeFillippi, 1990:88-102). 
Besides within the last decade conceptual fields of marketing function have been deeply discussed and role of managerial performance in marketing has been analyzed in literature mainly in two fields as marketability and role of marketing within strategy field. At the literature it is seen that marketing plays an important role in competitive advantage process. Innovation that is accepted as a central concept in search of a different advantage is the first role of marketing within competitive strategy. Customer monitors value based fundamental differentiation strategies, marketing research efforts of the administration and also monitors product improvement processes, marketing communication programs and selection of distribution processes at the target market. These processes require special capability of the administration which it owns to perform its services and to produce its products or to execute necessary activities via value chain (Morgan and Strong, 1998:1051-1073; Slater and Narver, 1995:63-74; Day, 1992:323-329; Varadajan, 1992:335-343; Kerin, 1992:331-334; Hutt et al., 1988:4-19; Day, 1994:37-51). At the strategic marketing literature, entrepreneur decision makers of the administration play significant roles in improvement of innovative products and services. Especially capability based sustainable competitive advantage theory shows that entrepreneur decision makers are significant factors during competitive advantage process. Administrations need to build and improve distinctive capabilities. Because at the end of this effort market opportunities are created and superior customer values are composed. In order the administrations to form the aforementioned opportunities and values, it is proved that entrepreneurship, innovative abilities, marketing capability and competitive advantage process are related with each other with strong bonds (Kerin, 1992:331-334; Knight, 2000:1232).

\section{Intensity of Entrepreneur}

At the literature it is shown that there is a positive relation in between "entrepreneurship" and growing focused efforts. An administration with entrepreneur structure is such that it chooses mostly innovation and initiates change and reacts rapidly and flexibly against changes. Strategic researches based on entrepreneur structured administration behavior model have gained popularity in recent years. Entrepreneurship has been conceptualized as an administration behavior and has shown itself as innovative, proactive and risk taking actions at strategic decisions of the administration. This means entrepreneurship is the idea of the administration to take risks, to create innovations and to create a new enterprise via active competitive behaviors. In this manner administrations aim to lead the market instead of following their competitors in obtaining present and future opportunities and in producing new products, services, technologies, process techniques and also aim to be in leader position at the market by growing, developing and creating innovations (Weerawardena, 2003:18; Naman and Slevin, 1993:137-153; Naktiyok, 2004:35; Zahra and Garvis, 2000:469-492; Pitt et al., 1997:344-350).

Innovative structure confronts us as new products, techniques or technological innovations of the administration, new ideas or an administration framework supporting innovative processes. Risk taking is effective for the administration to get into new formations by taking brave decisions. Being proactive requires to act as a leader instead of a follower in monitoring technologies and administrative techniques, formed innovations, products and services (Antoncic and Hisrich, 2003:16-18). At the behavior model of an entrepreneur administration, at the entrepreneur administration behavior model, it is required to analyze the market in the best possible manner by developing effective behaviors, by affording risks, by producing innovations for sustainable competitive advantage. 


\section{Marketing Capability}

Together with the integrated effect of ever increasing technological innovations in competition, importance of marketing capabilities has also increased. The reason is that focusing on only customer requirements, demands and pleasance is not sole requirement for success of the administration. Presenting of the unknown new product, process or services to the market and gaining the ones who are not previously the customers of the administration are required factors for success. All of these competition patterns emphasize the differences among administrations over the marketing capabilities axis (Papatya, 2007a:14). According to a study performed by Day as of (1994); marketing capability is defined as integrated processes allowing collective knowledge, skills and integrated processes which meet needs of the administration at the market for goods and services adding surplus values to be utilized by the administration (Day, 1994:37-52).

From this point of view, marketing capabilities are information based unique compositions which emerge as a result of coordination provided in between physical and non-physical resources of the administration. Besides, administrations should use their products, services and processes against their opponents in order to create a superior value and they should perceive the changes occurring in and out of the administration to create such a superior value and also they should react rapidly against such changes in order to act in a competitive manner (Papatya et al., 2007:425-434).

Unique marketing capabilities which the administration have are quite important regarding competitive advantage and these abilities have significant impacts over both financial performance and marketing performance (Fahy et al., 2000:63-81). Marketing capabilities are closely related with entrepreneurship and innovation levels of the administrations. Administrations which have an entrepreneur structure and which spend efforts for innovation have a more advanced marketing capabilities compared to their opponents.

Rizzoni has made a study as of (1991) and he has correlated in between entrepreneurism and organizational capabilities and innovation. Rizzioni (1991) mentions that innovation based strategy of the administration is a distinctive property compared to other administrations and it creates unique abilities against environmental variables. According to reference point of ability based theory, it is argued that whenever entrepreneur administrations build organizational innovation based competitive strategies they shall compose distinctive marketing capabilities (Rizzoni, 1991:31-42). Starting from this point, it is assumed that there is a relation in between entrepreneur intensity and marketing abilities and the obtained hypothesis is as follows:

\section{H1: There is a positive relation in between entrepreneur intensity and marketing capability}

\section{Organizational Innovation}

Innovation and competitive advantage process is closely related with each other at administrations. Administrations gain competitive advantage via innovative actions. Administration search for new ways in order to sustain their activities in value chain and to create a superior customer value. This is only possible via innovation. If ever innovation can form any value creation activity within administration then it shall lead competitive advantage. Similarly all innovation types lead to sustainable competitive advantage. At the strategical marketing literature, innovation based competitive strategy plays a dual role in marketing capability. First one of these roles has an impact over innovation development phase of the 
marketing capability. Second of these roles shows that marketing capability leads to the competitive advantage. At the evaluation of consumer requirements and competition, marketing capability plays a critical role in new product development phase and in sharing of ideas phase.

According to the previous researches, it is suggested that successful administrations should have adequate marketing resources and capability in order to develop a new product. New product development phase includes phases such as market research and concept test. Similarly, successful interface working effectively in between marketing and R\&D departments is a pre-condition to develop product (Weerawardena, 2003:20; Song et al., 1996:545-553; Calantone et al., 1993:337-351; Atuahene-Gima, 1995:275-293). Based on these discussions, it is seen that marketing capabilities have significant impact over innovations formed by the administration. Accordingly, it is assumed that there is a relation in between marketing abilities and organizational innovation and the obtained hypothesis is as follows:

H2: There is a positive relation in between marketing capability and organizational innovation.

\section{Sustainable Competitive Advantage}

At the study performed by Hunt and Morgan as of 1995, competitive advantage is defined as a superior customer value which is concluded by market domination and superior financial performance and/or a superior status in the market allowing success to be obtained by a relatively lower cost (Hunt and Morgan, 1995:5-6). At these studies, superior financial performance or "unearned income" are used as an indicator of competitive advantage. Similarly sustainable competitive advantage is only a competitive advantage sustains for a long period of time (Aharoni, 1993:31-49; Jacobson, 1988:415-430). Especially these opinions arguing usage of financial indicators have been criticized and the need of conceptualization of this structure including indicators supporting solid foundations for sustainable competitive advantage has emerged (Barney, 1991: 99-120; Day and Wensley, 1988:79-89). Responding to these critics, Day and Wensley (1988) has suggested to empower comprehensive market advantage indicators together with financial indicators.

Day and Wensley (1988) have also mentioned that one of the important keys in competition based measurement models is to evaluate distinctive capabilities during competitive advantage. At the functional structure suggested for ability based model, it should be determined the basis of competitive advantage which it has been established over and the followings should be analyzed; whether the administration has gained superior financial advantage and market advantage or not, whether the opponents have imitated the competitive strategy of the administration or not and what are the distinctive capabilities (Day and Wensley, 1988:79-89; Barney, 1991:99-120; Hall, 1993:607-618). So; competitive advantage basically emerges from innovation/development and change. Whenever administrations find a new foundation for competition or whenever they discover better tools for competition, they shall get the edge over their opponents (Papatya, 2007b:13). At the research related with innovation and administration performance, it is understood that innovation leads to a better performance (Lengnick-Hall, 1992:399-429). As a result, the following hypothesis has been obtained:

H3: There is a positive relation in between organizational innovation and sustainable competitive advantage. 
It is thought that role of marketing capabilities within sustainable competitive advantage is to ease success of market innovations. Comprehensive researches show that they have a significant impact over new products produced during marketing activities. Insufficient market analysis, sales, distribution and promotion efforts have negative impacts over the success of the new product. Product performance is a significant indicator for success at marketing activities. For this reason, it is asserted that marketing capability leads to sustainable competitive advantage (Song and Parry, 1993:125-133; Calantone and Di Benedetto 1988; 201-215; Schmidt, 1995:23-33; Cooper and Kleinschmidt, 1987:169-184). It is quite important for the administrations to have unique marketing capabilities in creating new markets. Whenever administrations have such unique capabilities, they shall have a significant competitive advantage in producing new products/services, in creating new business forms and in developing new channels (Papatya et al., 2007:429). The composed hypothesis at this point is as follows:

H4: There is a positive relation in between marketing capability and sustainable competitive advantage.

\section{Data Collection}

\section{RESEARCH METHODOLOGY}

Universe of the study is 1.062 manufacturing administrations located in Ankara province. While sampling is made throughout manufacturing administrations, basically product innovation and then all kinds of innovation researches performed within the administration have been effective in decision making. Another matter has been to prevent heterogeneity of technological processes used by administrations which have impacts over research results of the industry (Desss et al., 1990:8-13). Two sub sectors namely Main Metal Production and Fabricated Metal Products sectors have been selected among administrations which are active in manufacturing industry. These two selected sub-sector groups are active in metal based production activities and technological processes used by them are similar to each other.

In this two sector, questionnaires have been sent to 192 administration managers by a customized top letter. Later, mail and telephone contacts have been provided by these 192 administrations in order to get more responds from them. In total, 165 questionnaires have been answered. This means that $85 \%$ rate or return has been obtained. At the studies performed by participation of top management, $20 \%$ rate of return is accepted as satisfactory (Menon et al., 1996:304). As a matter of fact, responding rate is at a quite high level in this study.

\section{Measurements}

All of structures available at theoretical model have been measured by using multi scale. Used multi scales are explained in the following sections.

\section{Intensity of Entrepreneur}

Intensity of entrepreneur scale measures search of the administration for strategical leadership, innovation, proactivity and risk. Higher scores obtained in this scale show that decision makers of the administration have a higher tolerance about value, innovation, proactivity and risk. Statements used in the scale have been prepared by utilizing study performed by Namen and Slevin as of (1993). Alpha of the scale used in the study which has been performed as of 1993 is 0.81 . This scale is formed of three dimensions, namely; innovation, risk taking and being proactive. 


\section{Marketing Capability}

Marketing capability scale measures quality of customer services of the administration, effectiveness of advertisements, quality of sales power, power of distribution networks, power of marketing researches, speed of presenting new products and ability of differentiating products. Higher scores obtained in this scale show that the administration has adequate ability to use marketing tools and techniques. This scale used in this study is an adaptation of the scale used initially by Atuahene Gima at the study performed as of (1993).At the mentioned scale, 10 statements have been used and alpha of the scale has been 0.78 . Alpha of the scale in this study is 0.80 .

\section{Organizational Innovation}

Organizational Innovation shows that administration is functional regarding type and level of innovation. There are innovation types including product, process, management and marketing innovations. Higher scores obtained in this scale show that the administration is capable of bringing radical innovations for product, process, management and marketing systems. Alpha of the scale used in this study is 0.85 .

\section{Sustainable Competitive Advantage}

Competitive advantage scale shows the power of administrations against their opponents from innovation and different capabilities point of view. At composite measurement which has been performed in this study, study performed by Day and Wensley as of (1988) has been utilized. Regarding values of Sustainable Competitive Advantage, it is seen that not only financial performance but also inimitability of the administration and availability of distinctive capabilities are the foundations of competitive advantage. Higher scores obtained in this scale show the distinctive capabilities of the administration which it has against its opponents in order to obtain superior financial / market advantages. Alpha of the scale used in this study is 0.83 .

\section{Analysis Technique}

At the study, measurement models of the same type from each one of theoretical structure have been forecasted by using LISREL 8. Structural Equation Modelling (SEM) is important in evaluation of reliability of measurement models of the same type and in verification of unidimensionality. In present days, SEM is important because it is possible to test direct and indirect effects in between observable and non-observable variables within a single model (Joreskog and Sorbom,1996:21-26; Anderson and Gerbing, 1988:414-415; Meydan and Şeşen, 2011:5; Durukan and Hamşığlu, 2015:11). At the study, confirmatory factor analysis has been applied over the variables. Confirmatory factor analysis has been applied because it is an analysis at which it is tested whether a pre-defined and limited structure is verified or not as a model and confirmatory factor analysis has also been preferred in order to evaluate the construct validity. Besides, at the inter culture scale adaptation studies used by researches, it is suggested to start the analysis directly by confirmatory factor analysis. Since factor pattern of the mentioned tool at the original culture has been analyzed many times by qualitative and quantitative studies and experimental proofs related with construct validity have been determined (Çokluk et al.,2012:275-283; Şimşek, 2007:4; Durukan and Hamşıŏlu, 2015:11).

For these reasons, confirmatory factor analysis has been used in the study. Confirmatory factor analysis has been applied to every dimensions separately and variables spoiling the harmony have been eliminated from the study. At the following Table 1, statistical values about goodness, harmony and reliability of four structures are shown. Variables which have been obtained as a result of confirmatory factor analysis show that factor structure is in conformity. 
Acceptability of harmony values of the model which has been formed in accordance with these values are in good level (Schermelleh-Engel et al., 2003:23-74; Netemeyer et al., 2003:151-157; Bentler, 1990:238-246; Durukan and Hamşığlu, 2015:11).

Table 1: Goodness, Harmony and Reliability Values of Structures

\begin{tabular}{|l|c|c|c|c|c|c|c|c|c|c|c|}
\hline Structures & $\chi^{2}$ & S.D & $\chi^{2}$ & GFI & AGFI & RMSR & RMSEA & CFI & NNFI & NFI & Alpha \\
\hline $\begin{array}{l}\text { Intensity of } \\
\text { Entrepreneur }\end{array}$ & 92.34 & 36 & 2.57 & 0.94 & 0.91 & 0.045 & 0.073 & 0.96 & 0.95 & 0.95 & 0.81 \\
\hline $\begin{array}{l}\text { Marketing } \\
\text { Capability }\end{array}$ & 85.12 & 42 & 2.02 & 0.90 & 0.90 & 0.043 & 0.067 & 0.95 & 0.96 & 0.96 & 0.80 \\
\hline $\begin{array}{l}\text { Organizational } \\
\text { Innovation }\end{array}$ & 78.85 & 30 & 2.63 & 0.94 & 0.89 & 0.065 & 0.075 & 0.97 & 0.96 & 0.95 & 0.85 \\
\hline $\begin{array}{l}\text { Sustainable } \\
\begin{array}{l}\text { Competitive } \\
\text { Advantage }\end{array}\end{array}$ & 60.25 & 28 & 2.15 & 0.93 & 0.90 & 0.060 & 0.072 & 0.96 & 0.95 & 0.96 & 0.83 \\
\hline
\end{tabular}

At the evaluation of reliability of scales, Cronbach alpha test which is one of the most widespread methods has been utilized (Ravichandran and Rai,1999: 119-155; Jansson, 2000: 1446-1476). At literature, whenever Cronbach alpha coefficient is bigger than 0,70 , then the found value is accepted as satisfactory for internal reliability at social sciences (Baum and Wally, 2003: 1107-1129). At all of the used scale, alpha values are bigger than 0,70 and they are changing in between 0,80 and 0,85 . These values show that reliabilities of the scales are at higher levels.

In order to determine whether the structures have disintegration validity, average variance explained (AVE) have been separately calculated for each structure and these estimations have been evaluated together with correlation analysis results. The fact that AVE of each factor being bigger than squares of correlation coefficients of each other factors shows that scales have disintegration validity (Compeau and Higgins, 1995: 189-211; Fornell and Lacker, 1981: 39-50). At the following Table 2, average values, standard deviations, AVE and correlation values in between structures are shown.

Table 2: Average Values, Standard Deviation, AVE Values and Correlation Values in Between Structures

\begin{tabular}{|l|c|c|c|c|c|c|c|}
\hline Structures & $\mathbf{M}^{*}$ & $\mathbf{S S}^{* *}$ & $\mathbf{A V E}^{* * *}$ & $\mathbf{1}$ & $\mathbf{2}$ & $\mathbf{3}$ & $\mathbf{4}$ \\
\hline $\begin{array}{l}1 \quad \text { Intensity of } \\
\text { Entrepreneur }\end{array}$ & 3.89 & .767 & 0,75 & 1.000 & $0,65^{* *}$ & $0,73^{* *}$ & $0,66^{* *}$ \\
\hline $\begin{array}{l}2 \quad \text { Marketing } \\
\text { Capability }\end{array}$ & 4,20 & .811 & 0,72 & $0,65^{* *}$ & 1.000 & $0,68^{* *}$ & $0,61^{* *}$ \\
\hline $\begin{array}{l}\text { Innovation } \\
\text { Organizational }\end{array}$ & 4.05 & .860 & 0,80 & $0,73^{* *}$ & $0,68^{* *}$ & 1.000 & $0,72^{* *}$ \\
\hline $\begin{array}{l}4 \quad \text { Sustainable } \\
\begin{array}{l}\text { Competitive } \\
\text { Advantage }\end{array}\end{array}$ & 4,38 & .730 & 0,83 & $0,66^{* *}$ & $0,61^{* *}$ & $0,72^{* *}$ & 1.000 \\
\hline
\end{tabular}

(.)Average Value, ( . .) Standard deviation, ( $\cdots)$ Average variance explained (AVE), $\left({ }^{* *}\right)$ Correlation values are meaningful at $1 \%$ level.

After confirmatory factor analysis and validity and reliability analysis, structural models and hypothesis have been started to be examined. 


\section{CONCLUSIONS}

Forecast values of the structural model have been determined and hypotheses have been tested after measurement model of each structure is specified separately. Chi-square statistical value and degree of freedom of the structural model, $(=210.454, \mathrm{~S} . \mathrm{D}=95, / \mathrm{S} . \mathrm{D}=210.454 / 95=$ 2.21), and on the other hand, goodness harmony values have given consistent results for the structural model. Briefly; [ goodness of fit index GFI=, 0.92, root mean square RMS residual $\mathrm{RMSR}=0.068$, comparative fit index $\mathrm{CFI}=0.95$, normed fit index NFI=0.96, adjustment goodness of fit index AGFI=0.92, nonnormed fit index $\mathrm{NNFI}=0.95$, root mean square error of approximation RMSEA=0.074]. Marketing ability explains \%25.5, organizational innovation explains \%45.6 and Sustainable Competitive Advantage explains 28.8\% of the structural model and so additional support is provided for the structural model. Standardized parameter estimations and t-values for the structural model are shown in the following Table 3 . All of the parameter estimations have been found statistically meaningful. At the following Figure 1 hypotheses which have been formed under the conceptual framework and their relations are shown.

Table 3: Parameter Estimations Standardized for Final Model

\begin{tabular}{|l|c|c|}
\hline Road Analysis & $\begin{array}{c}\text { Parameter } \\
\text { Estimation }\end{array}$ & t-value \\
\hline H1-Intensity of Entrepreneur $\longrightarrow$ Marketing Capabilities & $\mathbf{. 7 6 8}$ & $\mathbf{7 . 4 6 7}$ \\
\hline H2- Marketing Capability Sustainable Competitive & $\mathbf{. 5 2 3}$ & $\mathbf{2 . 3 3 4}$ \\
\hline $\begin{array}{l}\text { H3- Organizational Innovation } \longrightarrow \text { Innovation Intensity } \\
\text { Advantage }\end{array}$ & $\mathbf{. 4 5 4}$ & $\mathbf{8 . 5 6 0}$ \\
\hline H4- Marketing Capability $\longrightarrow$ Sustainable Competitive Advantage & $\mathbf{. 6 7 8}$ & $\mathbf{3 . 6 6 8}$ \\
\hline
\end{tabular}

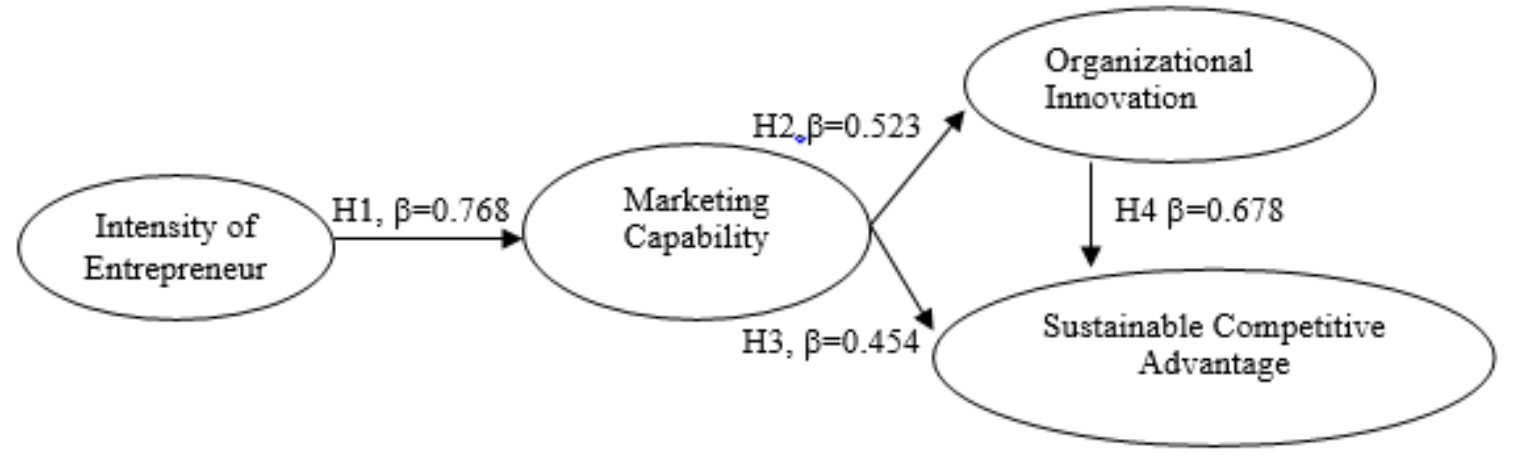

Figure 1: Conceptual Model Based on Hypotheses Relations

According to these obtained results, there is a powerful and positive relation in between intensity of entrepreneur and marketing capabilities according to $\mathrm{H} 1$ hypothesis $(\mathrm{b}=0.768$, $\mathrm{t}=7.467$ ), there is a partially powerful and a positive relation in between marketing capabilities and organizational innovation according to $\mathrm{H} 2$ hypothesis $(b=0.523, t=2.334)$, there is a comparatively powerful and a positive relation in between marketing capabilities and sustainable competitive advantage according to $\mathrm{H} 3$ hypothesis $(b=0.454, \mathrm{t}=8.560)$ and finally, there is a powerful and positive relation in between organizational innovation and sustainable competitive advantage according to $\mathrm{H} 4$ hypothesis $(b=0.678, t=3.668)$. As a result, composed $\mathrm{H} 1, \mathrm{H} 2, \mathrm{H} 3$ and $\mathrm{H} 4$ hypotheses have been accepted and research model that has been formed in theoretical framework has been fully verified.

\section{CONCLUSION AND RECOMMENDATIONS}

Findings obtained from the study have provided significant support for conceptual framework. Main subject of this study is that marketing capability, innovation based competitive strategy 
and distinctive capabilities are formed by entrepreneur decision makers of the administration. As in theoretical framework, competitive advantage hypothesis explains a significant portion of the variable. Marketing capabilities have a statistically meaningful and positive impact over organizational innovation and sustainable competitive advantage. Since marketing capabilities are determinative for innovative activities in administrations, they have impact over both technological and non-technological innovations. Besides, marketing capabilities also trigger the administration for it to obtain a continuous competitive advantage (Hutt et al., 1988:4-19; Day, 1992:323-329; Varadajan, 1992:335-343). Obtained findings show that intensity of entrepreneur is a significant determinative of the marketing capability and it also provides support for capability theory of sustainable competitive advantage. Administrations make efforts continuously to develop their marketing capabilities and to form distinctive capabilities in order to obtain competitive advantage. It is possible to mention that entrepreneur administrations are in an effort of organizational innovation.

The role of competitive strategy marketing function has been discussed in literature during recent years, however contributions of marketing capability which has a potential to contribute to mostly competitive strategy as a strategical ability over innovation based competitive strategy has been discussed in a conceptual manner. In this study, entrepreneurship, marketing capability, organizational innovation and sustainable competitive advantage have been tested in order to develop theoretical relations. At the findings; it has been seen that marketing capability plays a dual role and has an impact over both organizational innovation and sustainable competitive advantage. Besides, at the composed model it has been seen that decision makers play a key role in development of marketing capabilities. The study provides contribution to strategical marketing theory and for implementing people, results of this study play important role in development of competitive advantage. Limit of the study is that it has been performed at two selected manufacturing industry. It is foreseen that if ever sampling volume increase and different industries are selected then different results shall be obtained.

\section{References}

Aharoni, Y., (1993). "In Search fort the Unique: Can Firm Specific Advantages Be Evaluated?”, Journal of Management Studies, 30 (1), ss.31-49.

Anderson, J., C., ve Gerbing D., W., (1988). "Structural Equation Modeling in Practice: A Review and Recommended Two-Step Approach", Psychological Bulletin, 103(3), ss.411-423.

Antoncic, B., ve Hisrich, R., (2003). “Clarifying and Intrapreneurship Concept”, Journal of Small Business and Entreprise Venturing, 10 (1), ss.7-24.

Atuahene-Gima K., (1993). “Determinants of Inward Technology Licensing Intentions: An Emprical Analysis of Australian Engineering Firms”, Journal of Product Innovation Management, 10, ss.230-240.

Atuahne-Gima, K., (1995). “An Exploratory Analysis of The Impact of Market Orientation on New Product Performance: A Contingency Approach”, Journal of Product Innovation Management, 12, ss.275-293.

Barney, J., (1991). “Firm Resource and Sustained Competitive Advantage”, Journal of Management, 17(1), ss.99120.

Baum, R., J. ve Wally, S., (2003). "Strategic Decision Speed and Firm Performance",Strategic Management Journal, 24(11), ss.1107-1129.

Bentler, P.,M., (1990). “Comparative Fit Indexes in Structural Models”, Psychological Bulletin, 17(2),ss. 238-246.

Calantone, R.J., Di Benedetto, C., A, ve Divine R., (1993). “Organizational Technical and Marketing Antecedents for Successful New Product Development”, R\&D Management, 23(4),ss.337-351.

Calantone, R.J., Di Benedetto, C.A., (1988). “An Integrative Model of the NewProduct Development Process”, Journal of Product Innovation Management, 5 (September), ss.201-215. 
Durukan, T. \& Hamsioglu, A.B. (2016). The Role of Marketing Capabilities in Innovation Based Competitive Strategies: An Application on Production Businesses in Ankara. Advances in Social Sciences Research Journal, 3(11) 106-118.

Collis, D.,J., (1994). “Research Note: HowValuable are Organizational Capabilities?”, Strategic Management Journal, 15 (Winter), ss.143-152.

Compeau, D. R. ve Higgins, C. A., (1995). “Computer Self-Efficacy: Development of a Measure Initial Test”, MIS Quarterly, 19 (2), ss.189-211.

Cooper, R.G, ve Kleinschmidt, E.J., (1987). “New Product: What Separates Winners From Losers?”, Journal of Product Innovation Management, 4 (3), ss.169-184.

Çokluk, Ö., Şekercioğlu, G., ve Büyüköztürk, Ş., (2012), Sosyal Bilimler İçin çok Değişkenli İstatistik SPSS ve LİSREL Uygulamaları, Ankara: Pegem Akademi.

Day, G., S. (1994). “The Capabiliities of Market-Driven Organizations”, Journal of Marketing, 58 (October),ss.37-52.

Day, G., S., ve Wensley R., (1988). “Assessing Advantage: A Framework for Diagnosing Competitive Superiority”, Journal of Marketing, 52(April), ss.1-20.

Day, G.,S., (1992). "Marketing's Contribution to the Strategy Dialogue”, Journal of The Acadmy of Marketing Science, 20 (4), ss.323-329.

Dess, G., G., Ireland D., R., ve Hitt M., A.(1990). “Indusrty Effect and Strategic Management Research”, Journal of Management, 16 (1), ss.7-27.

Durukan T., Hamşığlu A.,B.,(2015). "Pazar Yönlülük, Pazarlama Yeteneklerinin Rekabet Avantajı Elde Etmede İhracat Performansı Üzerine Etkileri: Ankara İli İhracat İșletmelerinde Bir Uygulama”, Kırıkkale Üniversitesi, Ekonomi, İşletme, Siyaset ve Uluslararası İlişkiler Dergisi (JEBPIR), 1 (2), ss.1-19.

Fahy J., Hooley G., COX T., Beracs J., Fonfara K. ve Snoj B., (2000). “The Development and Impact of Marketing Capabilities in Central Europe", Journal of International Business Studies, 31 (1),ss.63-81.

Fornell, C. Ve Lacker, D., (1981). "Evaluating Structural Equation Models with Unobservable Variables and Measurement Error", Journal of Marketing Research, 18 (1), ss.39-50.

Grant, M., R., (2010). Contemporary Strategic Analysis, 7th Edition, John Wiley \& Sons, Ltd.

Hall, R., (1993). “A Fremework for linking Intangible Resource and Capabilities to Sustainable Competitive Advantage", Strategic Management Journal, 14, ss.607-618.

Hunt, Shelby D., ve Morgan, R., M., (1995). “The Comparative Advantage Theory of Competition”, Journal of Marketing, 59 (April), ss.1-15.

Hutt, M., D., Reingen, P.,H., ve Ronchetto, J., (1988). “Tracking Emergent Process in Marketing Strategy Formation”, Journal of Marketing, 52 (January), ss.4-19.

Jacobsen, R., (1988). “The Persistence of Abnormal Returns”, Strategic Management Journal, 9 (5), ss.415-430.

Jonsson, P., (2000). "An Empirical Taxonomy of Advanced Manufacturing Technology", International Journal of Operations \& Production Management,20(12), ss. 1446-1476.

Jöreskog, K.,G., ve Sörbom, D., (1993). LISREL 8. Structural Equation Modeling With The SIMPLIS Command Language, SSI Scientific Software International USA.

Kerin, R.,A., (1992). "Marketing's Contribution to the Strategy Dialogue Revisited”, Journal of The Academy of Marketing Science, 20 (4), ss.331-334.

Knight, R.,A., (1992). “Entrepreneurship and Marketing Strategy: The SME Under Globalisation”, Journal of International Marketing, 8 (2), ss.12-32.

Lado, A., A.,Boyd, N.,G., ve Wright, P., (1992). “A Competency-Based Model of Sustainable Competitive Advantage: Toward a Conceptual Integration”, Journal of Management, 18 (1), ss.77-91.

Lengnick-Hall Cynthia A., (1992). "Innovation and Competitive Advantage: What We Know and What We Need to Learn”, Journal of Management, 18 (2), ss.399-429.

Lippman, S.,A., ve Rumelt, R.,P., (1982). “Uncertain Imitability: An Analysis of Interfirm Differences in Efficiency Under Competition”, The Bell Journal of Economics, 13, ss.418-438.

Mahoney, J.,T., (1995). “The Management of Resources and Resource of Management”, Journal of Business Research, 33, ss.91-101. 
Menon A., Bharadwaj S., G. ve Howell R., (1996). "The Quality and Effectiveness of Marketing Strategy: Effect of Functional and Dysfunctional Conflict in Intraorganizational Relationship", Journal of the Academy of Marketing Science, 24 (4), ss.299-313.

Meydan, H., C., Şeşen, H., (2011). Yapısal Eşitlik Modellemesi AMOS Uygulamaları, Detay Ya., Ankara.

Morgan,R.,M., ve Strong, C.,A., (1998). “Market Orientation and Dimension of Strategic Orientation”, European Journal of Marketing, 32(11/12), ss.1051-1073.

Naktiyok, A., (2004). İç Girişimcilik, Beta Ya., İstanbul.

Naman, J., L., ve Slevin D., P., (1993). “Entrepreneurship and The Concept of Fit: A Model and Emprical Tests”, Strategic Management Journal, 14 (2), ss.137-153.

Netemeyer, R., Bearden, W. O. ve Sharma, S.(2003). Scaling Procedures: Issues and Applications, U.S.A: 2nd Edition Sage Publications, Thousand Oaks

Papatya N., (2007a). "Savaşçı İşletmelerin Rekabette Meydan Okuma Stratejisi: Kaynak Tabanlı Pazarlama Yaklaşımı”, Pİ: Pazarlama ve İletişim Dergisi ,6/20 (Nisan, Mayıs, Haziran), ss.14-21.

Papatya, N., (2007b). Sürdürülebilir Rekabetçi Üstünlük Sağlamada Stratejik Yönetim ve Pazarlama Odağı Kaynak Tabanlı Görüş, Asil Ya.

Papatya, N.,, Papatya G., ve Hamşığlu A.B., (2007). “KOBİlerin Rekabette Meydan Okuma Stratejisi: Sürdürülebilir Yenilik ve Pazarlama Yeteneklerinin Yapılandırılması”, 4. KOBİler ve Verimlilik Kongresi, (7-8 Aralık 2007), ss.425-434.

Peteraf, M.,, (1993). “The Cornerstones of Competitive Advantage”, Strategic Management Journal, 14 (3), ss.179192.

Piercy, N.,F., (1998). "Marketing Implementation: The Implications of Marketing Paradigm Weakness fort he Strategy Execution Process", Journal of The Academy of Marketing Science, 26 (3), ss.222-236.

Pitt, L., Berthon, P., ve Morris,M., (1997). "Entrepreneurial Pricing: The Cinderella of Marketing Strategy", Management Decision, 35 (5), ss.344-350.

Prahalad, C.,K., ve Hamel, G., (1990). “The Core Competence of the Corporation”, Harvard Business Review, 68 (3), ss.79-91.

Ravichandran, T. ve Rai, A., (1999). "Total Quality Management in Information Systems Development: Key Constructs and Relationship", Journal of Management Information System,14(3), ss.119-155.

Reed, R.,P., ve DeFillippi, R., (1990). “Causal Ambiguity, Barriers to Imitation and Sustainable Competitive Advantage”, Academy of Management, 15 (1), ss.88-102.

Rizzoni, A., (1991). “Technological Innovation and Small Firms: A Taxonomy”, International Small Business Journal, 9 (3), ss.31-42.

Schermelleh-Engel, K., Moosbrugger H.,ve Müller H., (2003). "Evaluating the Fit of Structural Equation Models: Test of Significance and Descriptive Goodness-of-Fit Measures” Methods of Psychological Research Online , 8(2), ss. 23-74.

Schmidt, J.B., (1995). “New Product Myopia: Which Activities Determine Success?”, Journal of Business and Industrial Marketing, 10 (1), ss.23-33.

Slater, C., C., ve Narver, J.,C., (1995). “Market Orientation and Learning Organization”, Journal of Marketing, 59, ss.63-74.

Song, X., M ve Parry M., E., (1993). “R\&D Marketing Integration Japanese High-Technology Firms: Hypotheses and Emprical Evidence”, Journal of the Academy of Marketing Science, 21 (Spring), ss.125-133.

Song, X.,M., Neely, S.,M., ve Zhao, Y., (1996). “Marketing R\&D- Marketing Integration in the New Product development Process", Industrial Marketing Management, 25, ss.545-553.

Şimşek, Ö., F. (2007), Yapısal Eşitlik Modellemesine Giriş- Temel İlkeler ve Lisrel Uygulamaları, Ankara: Ekinoks.

Teece, D.,J., Pisano, G., ve Shuen, A., (1997). “Dynamic Capabilities and Strategic Management”, Strategic Management Journal, 18 (7), ss.509-533.

Varadajan, P.,R., (1992). "Marketing's Contribution to Strategy: The View From A Different Looking Glass", Journal of The Academy of Marketing Science, 20 (4), ss.335-343. 
Durukan, T. \& Hamsioglu, A.B. (2016). The Role of Marketing Capabilities in Innovation Based Competitive Strategies: An Application on Production Businesses in Ankara. Advances in Social Sciences Research Journal, 3(11) 106-118.

Weerawardena, J., (2003). “The Role of Marketing Capabilitiy in Innovation-Based Competitive Strategy”, Journal of Strategic Marketing, 11, ss.15-35.

Zahra S., ve Garvis, D. (2000). "International Corporate Entrepreneurship and Firm Performance:The Moderating Effect of International Environmental Hostiliity”, Journal of Business Venturing, 15, ss.469-492. 